\title{
International Journal of Drug Policy A SYSTEMATIC REVIEW OF QUALITATIVE EVIDENCE ON BARRIERS TO AND FACILITATORS OF THE IMPLEMENTATION OF OPIOID AGONIST TREATMENT (OAT) PROGRAMMES IN PRISONS \\ --Manuscript Draft--
}

\begin{tabular}{|c|c|}
\hline Manuscript Number: & DRUGPO-D-19-514R3 \\
\hline Article Type: & Review Article \\
\hline Keywords: & prison, opioid, methadone, qualitative studies, systematic review. \\
\hline Corresponding Author: & $\begin{array}{l}\text { Rita Komalasari, Ph.D, M.D } \\
\text { Scotland, UNITED KINGDOM }\end{array}$ \\
\hline First Author: & Rita Komalasari, Ph.D, M.D \\
\hline \multirow[t]{4}{*}{ Order of Authors: } & Rita Komalasari, Ph.D, M.D \\
\hline & Sarah Wilson, Dr \\
\hline & Maya Puspitasari, PhD \\
\hline & Sally Haw, Professor \\
\hline Abstract: & $\begin{array}{l}\text { Background: } \\
\text { Opioid Agonist Treatment (OAT) programmes are regarded as a gold standard } \\
\text { treatment for people living with Opioid Use Disorders (OUDs). However, OAT } \\
\text { programmes are often unavailable or poorly implemented in prisons, in spite of the } \\
\text { large numbers of people living with OUDs and the high risk of HIV transmission in } \\
\text { prison settings. Unusually, this systematic review synthesizes qualitative evidence } \\
\text { relating to barriers to, and facilitators of, the implementation of OAT programmes in } \\
\text { prisons in high- and low/middle-income countries (LMICs) to provide more nuanced, } \\
\text { contextualised understandings of how prison stakeholders perceive and/or experience } \\
\text { OAT programmes within different prison settings. } \\
\text { Methods: } \\
\text { We systematically reviewed six electronic databases for studies published between } \\
\text { January } 2005 \text { and December } 2019 \text { involving prison stakeholders: policy-makers, } \\
\text { governors, healthcare staff, prison officers, and prisoners. The search identified } 8091 \\
\text { studies, of which only } 16 \text { incorporated qualitative methods (including qualitative } \\
\text { elements of mixed methods) and met our quality criteria. Four of these studies were } \\
\text { conducted in LMICs (Kyrgyzstan, Iran (2) and Indonesia). } \\
\text { Results: } \\
\text { Findings were organized under three broad themes: (1) perceived benefits of OAT } \\
\text { programmes; (2) barriers to the implementation and development of OAT programmes; } \\
\text { and (3) treatment processes. } \\
\text { Discussion: } \\
\text { A lack of a clear understanding of the roles of OAT programmes and doubts regarding } \\
\text { their effectiveness for people living with OUDs in prisons are critical barriers to prisoner } \\
\text { participation in both high-and LMIC countries. Prison systems, particularly in LMICs, } \\
\text { often lack the resources to mitigate problems with implementation. This review } \\
\text { highlights an urgent need to develop further qualitative studies into prison OAT } \\
\text { programmes, employing varied methods to explore such contexts in greater depth and } \\
\text { minimize the impact of harms relating to OUDs in prisons. }\end{array}$ \\
\hline
\end{tabular}

Accepted refereed manuscript of: Komalasari R, Wilson S, Puspitasari M \& Haw S (2021) A Systematic Review of Qualitative Evidence on Barriers to and Facilitators of the Implementation of Opioid Agonist Treatment (OAT) Programmes in Prisons. International Journal of Drug Policy, 87, Art. No.: 102978. https://doi.org/10.1016/j.drugpo.2020.102978

(c) 2020, Elsevier. Licensed under the Creative Commons Attribution-NonCommercial-NoDerivatives 4.0 International http://

creativecommons.org/licenses/by-nc-nd/4.0/ 


\section{Background:}

A systematic review and meta-analysis of drug use in prisons in mostly higher income countries reported that the prevalence of opioid use disorders (OUDs) among prisoners on entry into prison was $61 \%$ (for men) and 69\% (for women) respectively (Fazel et al. 2017). This represents a rise in prevalence since the 2000 s, when it was estimated to be between $48 \%$ for men and $60 \%$ for women prisoners (Fazel et al. 2006).

Other systematic reviews have indicated that one third of prisoners use illicit drugs while incarcerated (Mundt et al., 2018), with heroin the most commonly used drug (70\%) (Strang et al., 2005). Injecting heroin use poses a significant risk of transmission of bloodborne viral (BBV) infections, such as hepatitis B and C and human immunodeficiency viruses (HIV), a risk that increases in prison where needle and syringe exchange programmes are not available (Azbel et al., 2018, Altice et al., 2016, Jürgens et al., 2011). For example, $56 \%$ of HIV-infected prisoners in Culbert et al.'s (2015) study in two Indonesian prisons reported having injected heroin while in prison. Furthermore, 94.5\% of this same group confirmed having shared injecting equipment, with $80 \%$ having done so with more than ten other prisoners.

Opioid agonist treatment (OAT) programmes, involving the regular oral administration of long-acting opioid agonist drugs, such as methadone and buprenorphine, are regarded as an effective, evidence-based intervention for people with opioid dependence and for the prevention of HIV transmission among injecting drug users (IDUs) (WHO, UNAIDS and UNODC 2004). Quantitative reviews have indicated that OAT is effective in prison contexts. Notably, in New South Wales (Australia) Larney et al. (2010) found reductions of between $62 \%$ and $91 \%$ in illicit opioid use, between $47 \%$ and $73 \%$ in needle and syringe sharing, and between $55 \%$ and $75 \%$ in injecting drug use. Post-release OAT 
programmes have also been shown to reduce the likelihood of relapse back to the use of black market opiates and therefore the risk of re-incarceration (Malta et al. 2019).

The extant evidence therefore suggests that access to OAT programmes in prisons should be a public health priority, as recommended by the WHO since 1993. However, this recommendation has been ignored in many prison systems (Chandler et al., 2009) out of philosophical preferences for drug-free treatments, concerns relating to prison security, and widespread misconceptions and stigma associated with OAT programmes (Friedmann et al., 2012, McKenzie et al., 2009, Mitchell et al., 2009). As a result, OAT programmes remain unavailable in many prison settings (Sander et al., 2016).

As discussed, quantitative systematic reviews and meta-analyses have clearly demonstrated the effectiveness of prison OAT programmes. Drawing on a positivist research paradigm, these studies have investigated large samples, and used statistical tools to generate generalizable results. However, to build on this work and better understand the challenges of implementing and encouraging participation in OAT programmes, further exploration of how prison staff and prisoners perceive and/or experience these programmes within different prison settings is needed.

Therefore, in contrast to the great majority of systematic reviews, this review focuses on qualitative studies. Interpretivist studies allow for more nuanced and in-depth understandings of the specificities of local cultural, religious and economic contexts and of the varied meanings and purposes attached to OAT programmes in different settings. Such contextualised knowledge is essential for effective policy-making and implementation (Guba and Lincoln, 1994) but is often 
lost in quantitative studies through their use of the broader concepts required for quantification. Alongside Grella et al. (2020), this review is also one of the few such studies to examine barriers to and facilitators of OAT programmes in prisons from the perspective of both prison staff (policy-makers, prison officers and health care staff) and prisoners. The focus in this review on implications for prison systems in lower middle income countries (LMICs), and the involvement of researchers with experience of working in an LMIC prison system, should also be noted and reflect the initial purpose of this systematic review to support the development of a qualitative research project on the implementation of OAT programmes in Indonesia, where there are concentrated epidemics among people who inject drugs (UNAIDS DATA 2019), many of whom are incarcerated (Altice et al. 2016; Morineau et al. 2012).

\section{Research questions}

The SPICE framework was employed to help formulate research questions appropriate to a qualitative review. This framework is commonly used in public health research (Booth, 2006) as it helps both to clarify the nature of the problem and to provide a robust supportive framework for a systematic literature search, as outlined below. 
Table 1. SPICE anatomy of OAT programmes in prisons

\begin{tabular}{|c|c|c|}
\hline$S$ & Setting & Prison \\
\hline$P$ & Perspectives & $\begin{array}{l}\text { Different groups (policy makers, prison healthcare staff, } \\
\text { prison officers, and prisoners) }\end{array}$ \\
\hline I & Intervention & OAT programmes \\
\hline C & Comparison & Higher and low-middle income countries (LMICs) \\
\hline E & Evaluation & Perceptions and experiences of barriers and facilitators \\
\hline
\end{tabular}

The research questions developed for this review were:

1) What are the experiences of stakeholders, including policy makers, healthcare staff, prison officers and prisoners, in implementing, delivering or participating in OAT programmes?

2) What do stakeholders see as the barriers to and facilitators of existing OAT programmes?

3) From the perspective of stakeholders, what factors determine the successful implementation of OAT programmes in prisons?

4) What are the implications of these results for the implementation of OAT programmes in prisons in Indonesia and other LMIC countries?

\section{Review design}

This review follows the (UK) National Institute for Health and Clinical Excellence (NICE) protocol for the development of its Public Health Guidance. This protocol highlights the importance of developing and applying transparent criteria for 
inclusion and exclusion, data extraction, quality assessment, and data synthesis (NICE, 2012).

\section{Search strategy}

Grant (2004) warns that qualitative researchers may select different search terms and keywords from quantitative researchers, making such work more difficult to identify through database searches exclusively. Therefore, while database searches were the primary method used, the first author also undertook general Google searches, and checked through the reference lists of included studies.

A comprehensive database search strategy was used to locate relevant qualitative literature across the following electronic sources: ASSIA (Applied Social Science Index and Abstracts), CINAHL (Cumulative Index of Nursing and Allied Health Literature) via EBSCO HOAT, MEDLINE via Ovid, PUBMED, Social Science Citation Index via Web of Science, and PsycINFO via EBSCO Host. These searches combined the following search terms relevant to the review questions:

OAT: opioid, methadone, buprenorphine, drug or heroin in combination with use $^{*}$, addict ${ }^{*}$, depend*.

Prison: custod $^{*}$, detention, jail, remand, correctional facilities, prison, inmate, detainee, punishment, imprison, incarcerat*

Qualitative studies: qualitative or mixed methods study/research, thematic analysis, focus groups, ethnography, perspectives, knowledge, attitudes, experiences. 
The searches were limited to: primary research published between January 2005 and December 2019. Search languages were restricted to English.

$\underline{\text { Inclusion and exclusion criteria }}$

\section{Types of participants}

Studies were included if they involved one or more of the following three stakeholder groups: policymakers (prison governors, government representatives), prison staff (doctors, physicians, nurses, psychiatrists, substance use counsellors, drug workers, prison officers) and prisoners. Studies that included only former prisoners were excluded because the experience of current prisoners was thought to be more immediate or up-to-date. However, one study (Rhodes et al. 2019) with both current and former prisoners was included.

\section{Types of studies}

Studies were included if they involved any qualitative design elements, for example, ethnographic or interview-based studies. The qualitative elements of mixed-methods projects were included but studies that employed quantitative methods alone were not.

\section{Types of outcomes}

A range of outcomes was considered relevant, including the perspectives and experiences of policy-makers, prison officers, healthcare staff and prisoners on the implementation and delivery of OAT programmes in different countries with greater or lesser resources. The latter was particularly important given the focus of the project to which this review contributed on an LMIC prison system (in a 
predominantly Muslim country), Indonesia, in which the first author has experience of working.

\section{$\underline{\text { Selection process }}$}

The data search generated 8091 papers. The records were saved as text files and imported into RefWorks. 4968 duplicate papers were removed. The remaining 3123 papers were reviewed based on title and abstract for inclusion by the researcher with a minimum of $10 \%$ of the literature double-screened by another author (SH). After screening 3086 papers were excluded. In total, 37 papers were considered potentially relevant to the review, and full papers for these records were retrieved and read. Of these, 12 papers were identified as relevant to the review. A further four papers emerged through the additional searches described above. Overall, 16 papers met the selection criteria and were included in the review. A detailed overview of the selection process is shown in figure 1. 


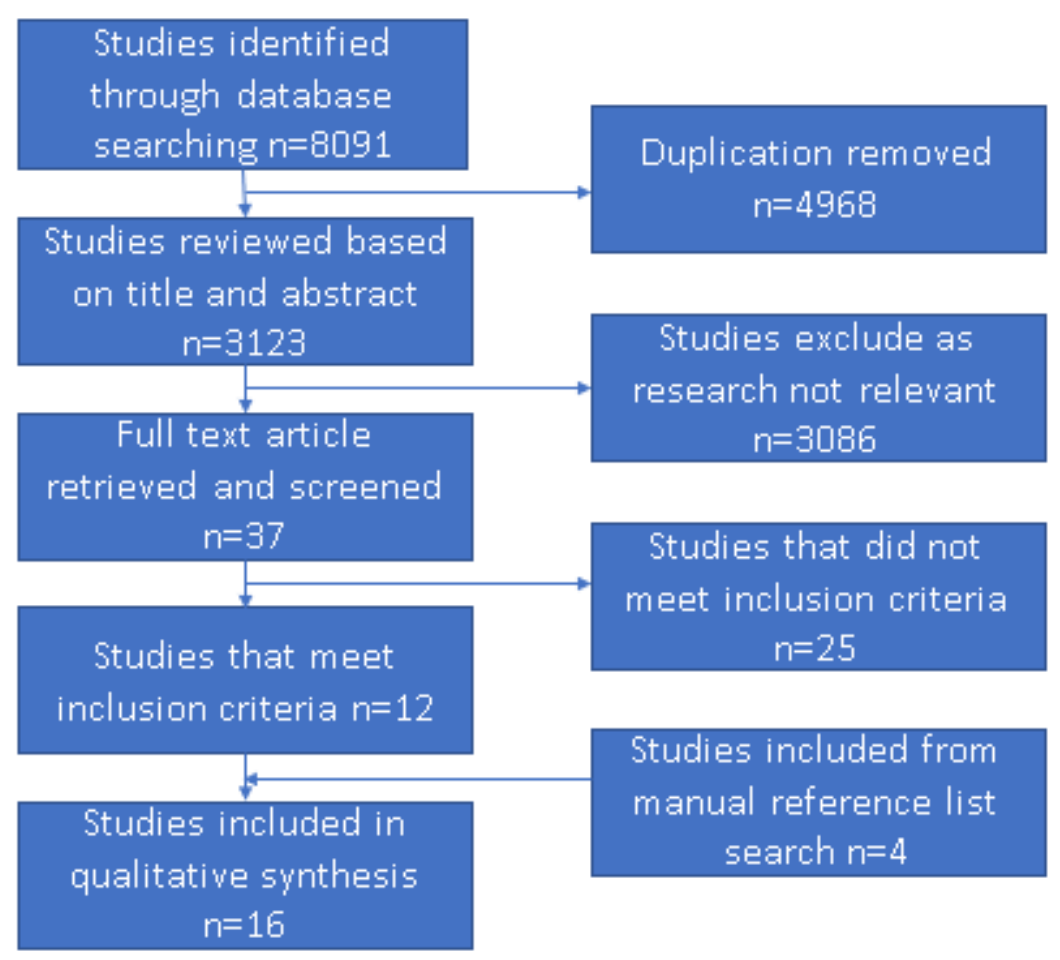

\section{Quality assessment}

Literature that met the inclusion criteria was then assessed for quality and methodological rigour using the quality appraisal checklist for qualitative studies developed by NICE (2012). This checklist has been used extensively in public health research to assess the validity of qualitative studies. It consists of 15 questions divided into seven sections: theoretical approach, study design, data collection, trustworthiness, analysis, ethics, and overall assessment. Two experienced qualitative researchers graded the studies for quality and disagreements were resolved by discussion.

\section{Articles selected}

Table 2 presents details of the studies reviewed. 
Table 2. Papers included in the review of barriers and facilitators to the implementation of OAT programmes in prisons

\begin{tabular}{|c|c|c|c|c|}
\hline Reference & Aim(s) of the research & Participants & Country & Design \\
\hline $\begin{array}{l}\text { Brinkley- } \\
\text { Rubinstein et } \\
\text { al., } 2017\end{array}$ & $\begin{array}{l}\text { To describe the perceived benefits } \\
\text { and challenges encountered by } \\
\text { participants in the RIDOC's } \\
\text { medications for addiction treatment } \\
\text { (MAT) program (methadone, } \\
\text { buprenorphine, naltrexone combined } \\
\text { with behavioural therapy) }\end{array}$ & $\begin{array}{l}40 \text { prisoners: } 28 \text { male, } 12 \\
\text { female prisoners. These } \\
\text { included } 20 \text { prisoners receiving } \\
\text { methadone, } 19 \text { buprenorphine } \\
\text { and } 1 \text {, naltrexone. }\end{array}$ & USA & $\begin{array}{l}\text { Qualitative study. } \\
\text { Semi-structured interviews. }\end{array}$ \\
\hline $\begin{array}{l}\text { Perkins and } \\
\text { Sprang, } \\
2013 .\end{array}$ & $\begin{array}{l}\text { To examine compassion fatigue, } \\
\text { burnout and job satisfaction of } \\
\text { substance abuse counsellors. }\end{array}$ & $\begin{array}{l}\text { Ten counsellors (female and } \\
\text { male) specialised in substance } \\
\text { dependency treatment. }\end{array}$ & USA & $\begin{array}{l}\text { Mixed methods. } \\
\text { Interviews with participants about self-perceptions } \\
\text { and their work as substance abuse counsellors. } \\
\text { Thematic analysis. }\end{array}$ \\
\hline $\begin{array}{l}\text { Awgu et al., } \\
2010 .\end{array}$ & $\begin{array}{l}\text { To increase knowledge of heroin- } \\
\text { dependent individuals and their } \\
\text { satisfaction with and perceptions of } \\
\text { methadone vs buprenorphine } \\
\text { treatment. }\end{array}$ & $\begin{array}{l}54 \text { methadone patients and } 60 \\
\text { buprenorphine } \\
\text { dependent men. }\end{array}$ & USA & $\begin{array}{l}\text { Mixed methods (unspecified) conducted during exit } \\
\text { interviews with prisoners. } \\
\text { The questionnaire collected primarily quantitative } \\
\text { data but some open-ended questions were also } \\
\text { included. These responses were coded } \\
\text { thematically. }\end{array}$ \\
\hline $\begin{array}{l}\text { Heimer et al., } \\
2006 .\end{array}$ & $\begin{array}{l}\text { To describe and evaluate a pilot } \\
\text { methadone maintenance programme } \\
\text { for heroin-dependent inmates. } \\
\text { To identify attitudes towards } \\
\text { methadone and programme } \\
\text { effectiveness. }\end{array}$ & $\begin{array}{l}60 \text { participants. } \\
\text { Five government agencies } \\
\text { created a cellblock and } \\
\text { adjacent space for the } \\
\text { provision of clinical, } \\
\text { psychological, and social } \\
\text { services for prisoners } \\
\text { participating in the pilot. }\end{array}$ & $\begin{array}{l}\text { USA } \\
\text { (Puerto } \\
\text { Rico) }\end{array}$ & $\begin{array}{l}\text { Mixed methods. } \\
\text { Qualitative data: open-ended interviews with } \\
\text { correctional officers focused on their beliefs about } \\
\text { methadone, the usefulness of the current } \\
\text { programme and its positive or negative effects. }\end{array}$ \\
\hline
\end{tabular}




\begin{tabular}{|c|c|c|c|c|}
\hline Reference & Aim(s) of the research & Participants & Country & Design \\
\hline $\begin{array}{l}\text { Mjåland, } \\
2016 .\end{array}$ & $\begin{array}{l}\text { To explore prisoners' and prison } \\
\text { staff members' perceptions on why } \\
\text { drug use occurs in prison in the } \\
\text { context of prison-based drug } \\
\text { rehabilitation programs. }\end{array}$ & $\begin{array}{l}21 \text { male prisoners: } 15 \text { prisoners } \\
\text { from drug rehabilitation unit and } \\
6 \text { prisoners from the OMT unit. } \\
11 \text { staff members: } 6 \text { prison } \\
\text { officers, } 2 \text { drug counsellors, a } \\
\text { psychologist, a social worker, a } \\
\text { nurse. }\end{array}$ & Norway & $\begin{array}{l}\text { Qualitative study. } \\
\text { Semi-structured interviews and participant } \\
\text { observation over } 8 \text { months of ethnographic fieldwork } \\
\text { in two drug rehabilitation programs (a drug } \\
\text { rehabilitation unit and an OMT unit). }\end{array}$ \\
\hline $\begin{array}{l}\text { Mjåland, } \\
2015\end{array}$ & $\begin{array}{l}\text { To explore the benefits of opioid } \\
\text { maintenance treatment (OMT) in } \\
\text { prison. }\end{array}$ & $\begin{array}{l}23 \text { prisoners and } 12 \text { staff } \\
\text { members. }\end{array}$ & Norway & $\begin{array}{l}\text { Qualitative study. } \\
\text { Semi-structured interviews. } \\
\text { Thematic analysis }\end{array}$ \\
\hline $\begin{array}{l}\text { Stöver et al., } \\
2006 .\end{array}$ & $\begin{array}{l}\text { To examine practices/policies for } \\
\text { the provision of substitution } \\
\text { treatment. }\end{array}$ & $\begin{array}{l}\text { Baseline study of } 15 \text { EU } \\
\text { countries involving ministerial } \\
\text { representatives, professionals } \\
\text { including service providers, } \\
\text { security officials and prisoners. } \\
33 \text { prisons across } 17 \text { countries } \\
\text { with a total number of } 184 \\
\text { prisoners ( } 132 \text { male and } 52 \\
\text { female prisoners). }\end{array}$ & EU & $\begin{array}{l}\text { Qualitative study. } \\
33 \text { Focus Group Discussions (FGDs). } \\
\text { Content analysis. }\end{array}$ \\
\hline $\begin{array}{l}\text { Page et al., } \\
2016 .\end{array}$ & $\begin{array}{l}\text { To explore the implications of the } \\
\text { recovery agenda for opiate } \\
\text { dependent prisoners in nine adult } \\
\text { pilot Drug Recovery Wings ( DRW) } \\
\text { prisons. DRWs emerged to } \\
\text { encourage long-term heroin users } \\
\text { receiving OAT to move towards } \\
\text { abstinence. }\end{array}$ & $\begin{array}{l}94 \text { DRW staff and } 102 \text { DRW } \\
\text { residents from } 9 \text { adult prisons. }\end{array}$ & UK & $\begin{array}{l}\text { Qualitative study. } \\
\text { Semi-structured interviews. } \\
\text { Emergent and grounded coding }\end{array}$ \\
\hline $\begin{array}{l}\text { Johnstone et } \\
\text { al., } 2011 .\end{array}$ & $\begin{array}{l}\text { To explore the use of Subutex } \\
\text { (buprenorphine) and its associated } \\
\text { effects. }\end{array}$ & $\begin{array}{l}14 \text { male opioid-dependent drug } \\
\text { users in seven Scottish prisons } \\
\text { who had experience of illicit drug } \\
\text { markets within the prison system. }\end{array}$ & $\begin{array}{l}\text { UK } \\
\text { (Scotland) }\end{array}$ & $\begin{array}{l}\text { Qualitative study. } \\
\text { Interviews focused on prisoners' subjective } \\
\text { experiences of Subutex (buprenorphine) } \\
\text { prescription. Constant comparative analysis. }\end{array}$ \\
\hline
\end{tabular}




\begin{tabular}{|c|c|c|c|c|}
\hline Reference & Aim(s) of the research & Participants & Country & Design \\
\hline Asher, 2013. & $\begin{array}{l}\text { To evaluate the broader aims and } \\
\text { potential consequences of maintaining } \\
\text { remand and short-term prisoners on } \\
\text { methadone. }\end{array}$ & $\begin{array}{l}63 \text { drug-using male prisoners } \\
\text { (aged 22-53), and } 11 \text { drug } \\
\text { workers in two local prisons in } \\
\text { the North of England. }\end{array}$ & $\begin{array}{l}\text { UK } \\
\text { (England) }\end{array}$ & $\begin{array}{l}\text { Qualitative study. } \\
\text { In-depth semi-structured interviews. } \\
\text { No information about the methods of data analysis. }\end{array}$ \\
\hline Carlin, 2005. & $\begin{array}{l}\text { To explore staff and prisoner } \\
\text { perceptions of prison methadone } \\
\text { maintenance programmes. }\end{array}$ & $\begin{array}{l}15 \text { prisoners and } 16 \text { prison staff } \\
\text { (management, nurses, medical } \\
\text { orderlies and } 11 \text { prison } \\
\text { officers). }\end{array}$ & $\begin{array}{l}\text { Republic } \\
\text { of Ireland }\end{array}$ & $\begin{array}{l}\text { Exploratory study. } \\
\text { Purposive and snowball sampling. } 31 \text { semi- } \\
\text { structured interviews with prisoners and prison } \\
\text { staff, } 8 \text { FGDs with prisoners. } \\
\text { Thematic analysis. }\end{array}$ \\
\hline $\begin{array}{l}\text { Larney et al., } \\
2017 .\end{array}$ & $\begin{array}{l}\text { To examine prisoners' reasons for } \\
\text { seeking OAT in custody, and intentions } \\
\text { regarding continuation or cessation of } \\
\text { treatment prior to and following release. }\end{array}$ & $\begin{array}{l}46 \text { prisoners from seven } \\
\text { correctional centres: } 32 \text { male } \\
\text { and } 14 \text { female prisoners. }\end{array}$ & $\begin{array}{l}\text { Australia } \\
\text { (New } \\
\text { South } \\
\text { Wales- } \\
\text { NSW) }\end{array}$ & $\begin{array}{l}\text { Qualitative study. } \\
\text { Semi-structured interviews. } \\
\text { Thematic analysis. }\end{array}$ \\
\hline $\begin{array}{l}\text { Moradi et al., } \\
2015 .\end{array}$ & $\begin{array}{l}\text { To assess the advantages and } \\
\text { shortcomings of methadone } \\
\text { programmes from the perspective of } \\
\text { those involved in the delivery of prison } \\
\text { healthcare. }\end{array}$ & $\begin{array}{l}14 \text { FGDs with a total of } 140 \\
\text { participants } \quad \text { including } \\
\text { physicians, directors and and } \\
\text { experts, onsultants, } \\
\text { managers of prisons from } \\
\text { different prisons across Iran. }\end{array}$ & Iran & $\begin{array}{l}\text { Qualitative study. } \\
\text { Purposive sampling. } 14 \quad \text { FGDs with prison } \\
\text { managers and physicians. } \\
\text { Content and thematic framework analysis. }\end{array}$ \\
\hline $\begin{array}{l}\text { Zamani et al., } \\
2010 .\end{array}$ & $\begin{array}{l}\text { To investigate the context in which } \\
\text { methadone maintenance programme } \\
\text { was provided for opioid-dependent } \\
\text { prisoners, and to identify barriers to the } \\
\text { further scaling-up of methadone } \\
\text { programmes. }\end{array}$ & $\begin{array}{l}30 \text { male prisoners, } \\
15 \text { staff including physicians, } \\
\text { nurses, psychologists, prison } \\
\text { managers and four health } \\
\text { policymakers. }\end{array}$ & Iran & $\begin{array}{l}\text { This paper represents the qualitative phase of a } \\
\text { longitudinal mixed-methods study. } \\
\text { Purposive sampling, seven FGDs with prisoners, } \\
\text { and semi-structured interviews with staff. } \\
\text { Thematic analysis. }\end{array}$ \\
\hline
\end{tabular}




\begin{tabular}{|c|c|c|c|c|}
\hline Reference & Aim(s) of the research & Participants & Country & Design \\
\hline $\begin{array}{l}\text { Rhodes et } \\
\text { al., } 2019 .\end{array}$ & $\begin{array}{l}\text { To explore the implementation of an } \\
\text { internationally-supported programme of } \\
\text { methadone treatment. }\end{array}$ & $\begin{array}{l}22 \text { male prisoners with histories } \\
\text { of injecting drug use and } 21 \\
\text { prison staff members in three } \\
\text { prisons in Bishkek between } \\
2016 \text { and } 2018 \text {. }\end{array}$ & Kyrgyzstan & $\begin{array}{l}\text { A qualitative case study. } \\
\text { Semi-structured interviews and observation. } \\
22 \text { interviews before and } 20 \text { interviews after } \\
\text { release from prison. } \\
\text { Constructivist grounded analysis. }\end{array}$ \\
\hline $\begin{array}{l}\text { Culbert et } \\
\text { al., } 2015 .\end{array}$ & $\begin{array}{l}\text { To examine the prevalence, correlation, } \\
\text { and social context of injecting drug use } \\
\text { among HIV-infected male prisoners in } \\
\text { Indonesia. }\end{array}$ & $\begin{array}{l}102 \text { HIV-infected male } \\
\text { prisoners aged } \geq 18 \text { years from } \\
\text { one narcotics and one non- } \\
\text { narcotics prison. }\end{array}$ & Indonesia & $\begin{array}{l}\text { Mixed-methods. } \\
\text { Semi structured interviews on the socio- } \\
\text { environmental context of injection drug use. } \\
\text { Thematic analysis. }\end{array}$ \\
\hline
\end{tabular}


Characteristics of the studies included in the review

Four studies employed mixed-methods (Culbert et al., 2015, Perkins and Sprang, 2013, Awgu et al., 2010, Heimer at al., 2006). All the studies conducted either semistructured or open-ended interviews, focus groups or observation to collect data. Six studies assessed methadone and/or buprenorphine detoxification and/or maintenance programmes (Larney et al., 2017, Rubinstein et al., 2017, Perkins and Sprang, 2013, Johnstone et al., 2011, Stöver et al., 2006, Asher, 2013), while the remaining studies reviewed methadone maintenance programmes alone. Only four studies were conducted in LMIC countries (Kyrgyzstan, Indonesia and Iran) (Rhodes et al., 2019, Culbert et al., 2015, Moradi et al., 2015, Zamani et al., 2010).

\section{Method of qualitative synthesis}

Following NICE guidelines, coding of the selected articles began with a review of each line and paragraph of the articles identified, guided by the review questions. The codes identified through this process were entered into an Excel spreadsheet to generate an initial list of codes. The similarities and differences between the codes were compared and themes found to be related conceptually were grouped into categories. Three central themes emerged from this process:

\section{Perceived benefits of OAT programmes}

2. Barriers to the implementation and development of OAT programmes

3. Treatment processes.

Within each theme, barriers to, and facilitators of, the implementation and delivery of, and participation in, OAT programmes were identified. 


\section{Findings}

\section{Perceived benefits of OAT programmes}

In general, all stakeholders considered OAT programmes to be beneficial to prisoners, to prisoners' families and to prison systems. Benefits identified by prisoners included reduction in the sharing of injecting equipment, thus reducing the risk of BBV infections; improvements in health (Larney et al., 2017, Zamani et al., 2010, Carlin, 2005); the alleviation of craving and heroin withdrawal symptoms (Larney et al., 2017, Brinkley-Rubinstein et al., 2017, Moradi et al., 2015, Awgu et al., 2010, Stöver et al., 2006, Carlin, 2005), and improvements in prisoners' financial situation and social lives while incarcerated (Moradi et al., 2015, Carlin, 2005). One US prisoner drew on religious language to communicate the sense of relief that participation in the programme had afforded them:

"I don't have to worry about getting something off somebody and doing that whole criminal activity or owing people anything. I do my own program in here, and I'm good. I don't need anything else. It's a blessing" (Brinkley-Rubinstein et al., 2017, p. 3).

Benefits for families included a reduction in prisoners' need for financial support (Larney et al., 2017, Asher, 2013, Zamani et al., 2010, Carlin, 2005), especially in LMIC contexts where families must provide food, participation in prison services is not always free and the extremely low staff pay meant that prisoners often needed to pay bribes. Prisoners' participation in methadone programmes similarly reduced their expenditure on illicit drugs. This reduction in prisoner debt also afforded families a 
greater sense of assurance about their relatives' safety while in prison (Zamani et al., 2010).

Several studies similarly found that the availability and consumption of illicit drugs in prisons reduced, and that consequently, prisoners were less tense, easier to manage and that there were fewer drug-related crimes committed in these prisons (BrinkleyRubinstein et al., 2017, Moradi et al., 2015, Asher, 2013, Zamani et al., 2010, Carlin, 2005). Feelings of greater security linked to the implementation of prison OAT programmes were also expressed by an Iranian staff member:

"There has been an obvious reduction in escape, riot, tension, conflict and self-injury among the prisoners, especially addicts, after the introduction of the MMT" (Moradi et al., 2015, p. 585).

Relatedly, prison systems also benefited through improved staff morale. For example, the reduction in the dangers posed to staff members by injecting equipment, and the higher rates of treatment among prisoners receiving OAT programmes, were associated in some contexts with feelings of greater security at work and pride at having changed something for the better. An Iranian prison officer illustrates these points, highlighting the proportion of prisoners treated:

"Implementation of this program has meant that we do not see injecting tools to the same extent anymore; I cannot say there are not any at all, but their use has been reduced significantly, [and] we have treated over 90\% (of the drug injectors) with methadone" (Zamani et al., 2010, p.169). 
OAT programmes have also been associated with the increased uptake of other prison services (Stöver et al., 2006), including counselling, education sessions, and sports (Moradi et al., 2015).

\section{Barriers to the delivery and development of AT programmes}

While studies have demonstrated benefits for prisoners, their families and prison staff, significant barriers to the delivery of, and prisoner participation in these programmes have also been identified (Grella et al. 2020). This review identified similar barriers including the availability of illicit drugs, low levels of understanding about the OAT programmes among both staff and prisoners, concerns about withdrawal, and the stigma associated with participating in methadone programmes.

\section{Availability of illicit drugs}

In many places, the easy availability of illicit drugs in prisons made it difficult for prisoners to remain abstinent from illicit drugs during treatment (Mjåland, 2016, Page et al., 2016, Culbert et al., 2015, Asher, 2013). Indeed, low prison staff pay, particularly in LMIC countries, meant that working in prisons was often a secondary not a primary job, and prison officers were suspected of bringing drugs into prisons to sell in order to supplement their low pay (Moradi et al., 2015).

Furthermore, other prisoners encouraged those on OAT programmes to continue using illicit drugs. As a result, prisoners progressed from inhalation to injection in prisons to deal with their consequent increased tolerance for heroin (i.e. the need for

a larger quantity of drug to achieve the same subjective effects) (Asher, 2013, Johnstone et al., 2011, Zamani et al., 2010). 
A recurrent barrier to the efficient delivery of prison OAT programmes was the lack of understanding among all prison stakeholders of the purposes of OAT programmes and their role in reducing the harms associated with the injection of illicit opiates.

Prisoners and prison officers often understood the function of OAT programmes in relation to the alleviation of heroin withdrawal symptoms, but rarely in terms of the reduction of associated harms (Stöver et al., 2006, Carlin, 2005). As Moradi et al. found:

"Objectives are unknown for inmates and officials; there are great expectations about the therapeutic effects of methadone treatment programs, while these expectations are not among the [programmes] main objectives" (2015, p.587).

Strikingly, objectives relating to harm reduction -namely the reduction of blood-borne diseases such as HIV and hepatitis B and C infection associated with sharing used equipment - were recognised in only one study (Larney et al., 2017).

Such gaps in understanding were sometimes reinforced, and the effectiveness of the programmes in harm reduction terms distorted, by the means adopted by prison authorities to measure or audit success. Notably, where uptake rates were used as indicators of success, healthcare workers felt pressured to include non-opioid injecting drug users in their programmes (Moradi et al. 2015, Stöver et al., 2006), while successful programmes were sometimes assessed as failing because of low participation rates (Moradi et al., 2015, Asher, 2013). 
Prison staff also used the programmes for their own purposes. Several studies highlighted that prison staff and prisoners associated the introduction of OAT programmes with the control and regulation of prisoners' behaviour (Carlin, 2005). Methadone was used either as a reward (Stöver et al., 2006), or punishment (Moradi et al., 2015) in such instances. Prisons were described as highly tense environments, in which prison officers were under great pressure and would use whatever means were at their disposal to maintain order. As one prison officer in the Republic of Ireland put it:

"My understanding is that methadone keeps a lid on the prison. It stabilized prisoners who are taking drugs. Methadone helps them to mellow out" (Carlin, 2005, p.413).

The lack of understanding of the effects and function of methadone

Studies in the US, UK, EU, Iran, Kyrgyzstan and Indonesia all found that concerns relating to the perceived side-effects of methadone deterred participation. Both prisoners and their families viewed methadone withdrawal as worse than heroin withdrawal, and even as lethal (Rhodes et al., 2019, Johnstone et al., 2011, Zamani et al., 2010, Stöver et al., 2006, Carlin, 2005). Qualitative data made the strength of these fears clear:

"A person beings to transform from a human into an animal. They have ulcers, all of them. All of them are rotting, and such a smell. It's [the methadone treatment programme] like a monkey house. People are already not normal" (Rhodes et al., 2019, p.1625; a prisoner in the Kyrgyzstan). 
"Methadone will stop the craving, but will kill you quicker. It is better just to take heroin" (Culbert et al., 2015, p. 75; a prisoner in Indonesia).

Another recurrent misconception was that methadone programmes simply substituted one drug dependence for another (Asher, 2013, Stöver et al., 2006, Carlin, 2005):

"I came in [to prison] on methadone....and I came off because basically I did not want to be on it anymore; I thought it was basically replacing one addiction with another" (Larney et al., 2017, p.307; a prisoner in NSW).

Some of the comments reported around methadone did not reflect a straightforward rejection of OAT programmes, but rather a preference for the use of buprenorphine over methadone by staff and prisoners (Asher, 2013). Prisoners often reported more positive experiences in reducing withdrawal and craving from opioids with these drugs (Larney et al., 2017, Johnstone et al., 2011, Awgu et al., 2010) but their availability is limited in prisons (Larney et al., 2017, Brinkley-Rubinstein et al., 2017, Johnstone et al., 2011, Awgu et al., 2010).

Fear of stigmatisation

Fear of stigmatisation also affected OAT participation and ultimately limited the expansion of such programmes (Culbert et al., 2015). Notably, Stöver et al., (2006) found that on admission to prisons across the EU many prisoners avoided accessing medical treatment for this reason. The lack of confidentiality in dispensing methadone also undermined some prisoners' self-image (Carlin, 2005). These problems were particularly pronounced in the studies in LMIC. Negative stereotypes were attributed 
to OAT programme participants by other prisoners and prison staff at all levels. OAP participation was linked to homosexuality, poverty, being of lower class, being a traitor, and having AIDS (Rhodes et al., 2019, Culbert et al., 2015, Moradi et al., 2015, Zamani et al., 2010):

"Those who are not taking methadone think that those who are receiving methadone either have AIDS or, I apologize for saying this, have became lasshi [an offensive term for a homosexual man] and cannot afford to buy drugs" (Zamani et al., 2010, p. 170; Iran).

In contrast, a few studies found that prison staff held less stigmatising attitudes towards prisoners receiving methadone as compared to heroin users when they had a better understanding of prisoners' backgrounds (Moradi et al., 2015, Johnstone et al., 2011, Carlin, 2005). Sometimes such understandings drew upon a family history of addiction (Perkins and Sprang, 2013).

Systemic problems affecting the delivery of, and participation in, prison OAT programmes

Prison systems and structures can also affect the delivery of OAT programmes, through the provision of insufficient resources to support them and by restricting the time-frame in which participation is possible.

In many places studied, there were no supportive prison policies or guidelines, and where they did exist, implementation varied (Stöver et al., 2006). Furthermore, the duration of OAT programmes was often very limited as a result of being linked closely to prisoner admission or release dates. For example, treatment was provided only at 
these times or was strictly time-limited to periods of between six and twelve months (Stöver et al., 2006).

A lack of treatment continuity when prisoners were transferred to prisons without OAT programmes was another common problem. In many contexts, the continuity of treatment between prisons was low when compared to between community-based services (Stöver et al., 2006, Carlin, 2005). Prisoners often faced problems on release as a result of inadequate prison-community services referral systems (Zamani et al., 2010). In such circumstances, they needed to draw on family help or try to make their own referrals, as explained by a US prisoner.

"if they [family] can't do it for you, like you have to have a way to do it yourself" (Brinkley-Rubinstein et al., 2017, p.5).

In response to such inadequate referral systems across the EU, Stöver et al. (2006) suggested conducting regular meetings among prison staff, and greater collaboration between institutional prisons and the community OAT programmes services.

A lack of funding and resources is widespread and a considerable barrier to continuing and to scaling-up OAT programmes in prisons since it often led to a lack of staff, of staff training and of equipment and space. This reinforced prisoners' concerns about privacy and confidentiality mentioned above (Heimer et al., 2006b). Psychosocial services were frequently unavailable or not fully integrated into prison OAT programmes (Zamani et al., 2010, Heimer et al., 2006b). This situation has persisted despite the recognition that such services -involving psychologists, pedagogues, educators, and social workers- can be critical to maintaining lower methadone doses (Stöver et al. 2006, Moradi et al. 2015) and to increasing retention and reduced relapse 
(Stöver et al., 2006 Brinkley-Rubinstein et al., 2017, Johnstone et al. 2011). Staff shortages were also associated with increased work pressure (Carlin, 2005), longer waiting lists (Zamani et al., 2010) and higher rates of methadone diversion due to a lack of supervision (Moradi et al., 2015, Zamani et al., 2010).

These problems were particularly acute in LMIC where prisoner to prison staff ratios are much higher. As Moradi et al. explain: "[s]hortage of budget, staff, equipment and facilities [...]. These deficiencies sometimes cause the programs to be stopped" (2015, p.587). Several studies also noted a lack of community-based services. In Iran, most community programmes were concentrated in urban centres. As such, many exprisoners from rural areas registered for urban OAT programmes leading to long waiting lists (Zamani et al., 2010). As noted, this lack of resources also increased the burden on families who were expected to provide greater financial support.

\section{$\underline{\text { Treatment procedures and practices }}$}

Treatment procedures and practices and a lack of space in prison also affected access to and participation in prison OAT programmes, particularly in LMIC countries.

\section{Admission criteria}

In some non-"western" countries, the requirement for family consent presented a significant barrier to prisoner participation. Many prisoners found it difficult to obtain such consent since some had been rejected by their families, while other families knew nothing of their drug use (Culbert et al., 2015). In such contexts, the use of uptake rates as an indicator of success, as discussed above, is particularly problematic (Moradi et al., 2015). 


\section{Dispensing practices}

Rigid dispensing practices and lack of confidentiality were problematic in many places. In one study the process of dispensing drugs was described as "chaotic". The use of de-humanising imagery was also common in describing these processes. Prison staff described prisoners as "lions around the carcass of a dead animal", while prisoners felt they were shepherded around like "cows or sheep" (Carlin 2005, p.412). Often prisoners were required to attend a daily methadone clinic (Johnstone et al., 2011, Awgu et al., 2010) leading to a lack of privacy, since prison staff and other prisoners were able to identify those attending as drug users (Mjåland et al., 2015, Awgu et al., 2010, Carlin, 2005). Their comparison of practices across the EU led Stöver et al. (2006) to recommend that methadone either be dispensed alongside other medication or that prisoners receiving methadone should be allocated to one unit to better protect their confidentiality and, therefore, reduce their exposure to stigma.

Prison staff often defended such non-confidential practices as necessary to combat high rates of non-adherence and diversion, the latter being used by prisoners to obtain money or relief from bullying (Larney et al., 2017). Such diversion was possible where there was a lack of healthcare staff supervision and prisoners received higher doses than they felt they needed (Mjåland et al., 2015, Zamani et al., 2010). In higher income countries, diversion often reflected profit-related motivations whereas in LMIC countries, this practice also reflected prisoners' substantial need for money while in prison, as discussed above. However, although many prisoners in the two Iranian studies (Moradi et al., 2015, Zamani et al., 2010) reported diversion issues, these aspects were often unrecognised by policy makers when they planned to scale-up prison-based OAT programmes (Heimer et al., 2006b). 


\section{Discussion}

Very few reviews have conducted an in-depth analysis of qualitative evidence to explore the diverse perspectives and experiences of the wide range of stakeholders involved in OAT programmes (policymakers, prison officers, healthcare staff and prisoners), or to identify elements of prison contexts and OAT programmes that act as barriers to, or motivating factors for the implementation and maintenance of, and prisoner participation in such programmes. As a result, the importance of context, and of stakeholder understandings of the policies around, and reasons for, implementing of OAT programmes has been vastly underestimated.

Although the cultural, resource and policy contexts of the studies reviewed differed greatly, constraints on delivery were reported across all countries where qualitative data have been collected on the implementation and delivery of OAT programmes in prisons. This finding is consistent with those of Grella et al. (2020). Common systemic issues included disruption resulting from the limited length of treatment periods and problems relating to prisoner transfer and post-release support. The research conducted in the UK, EU, and US highlighted problems relating to transfer between prisons because of the low coverage of OAT programmes across prisons compared to those in the community. In LMIC countries, a lack of treatment in community settings alongside a lack of referral systems amplified these problems greatly.

Studies in countries such as the US and the UK, were less likely to report barriers to resources in prisons when compared to those conducted in LMICs, suggesting that the programmes have received greater and more consistent support in high-income countries. Many prisoners have emphasised a need for psychosocial support in prison OAT programmes, and for more individualized and structured counselling in 
Medication-Assisted Treatment (MAT) programmes (OAT programmes combined with behavioural therapy) to help overcome drug use problems and improve physical, and psychosocial health conditions (Jhanjee, 2014). However, research in LMIC prison systems reported much higher prisoner-staff ratios and much less funding for such complementary services. As such, and combined with the lack of other harm reduction strategies such as needle, syringe and bleach distribution programmes, these studies reaffirmed prisons as high risk environments (Rhodes, 2002) for HIV transmission particularly in LMIC settings.

Overall, there was a clear lack of understanding of the role of OAT programmes as part of harm reduction programmes. Often these misunderstandings seemed to reflect notions of prisons as exclusively places of punishment rather than rehabilitation. Indeed, in one of the LMIC settings (Iran), these misunderstandings were also associated with punitive practices by prison staff (Moradi et al., 2015). Furthermore, many prisoners doubted that OAT programmes could help them. They feared the side effects of methadone and associated withdrawal symptoms more than those of illicit heroin. As a result, the authors of some studies recommended providing alternative treatment options such as non-injectable buprenorphine to overcome these concerns.

Stigmatising attitudes towards prisoners' participation in OAT programmes were also reported by all stakeholders in both high income-and LMIC countries. As indicated in a previous study (Gordis, 1991), these attitudes discouraged prisoner participation and prevented programmes from being scaled-up. In some higher income countries, vulnerability to stigmatisation has been reduced and participation improved by providing greater privacy during the dispensing of drugs. In the LMIC countries studied, the stigma associated with drug use might prevent any engagement with OAT 
programmes since family consent to treatment is often required, but often denied or never requested due to this stigma.

\section{Strengths and Limitations}

The strength of this review lies in its focus on qualitative data, which has revealed important barriers to the implementation of, and participation in, OAT programmes in prison. It also provides valuable insights into some of the determinants of the successful delivery of the OAT programmes in different contexts. This approach provides a much more holistic and comprehensive view to inform the development of OAT policies and practices than is possible from focusing on quantitative reviews alone.

Concerning the search strategies employed, it is possible that some relevant studies were missed. The researcher mitigated this possibility, at least in terms of papers published in English, by searching for relevant reference lists from the included studies. Although mixed methods papers were included, the researcher found only a small number of qualitative studies which met the inclusion criteria for the review. As Grella et al. (2020) also found, this observation indicates a significant lack of qualitative studies on OAT programmes in prisons. Other limitations were that only papers published from countries where OAT is available in prison were included in the review and that studies of former prisoners were excluded. On reflection, including studies of former prisoners might have provided a broader perspective, as it is likely that they would have been able to speak more openly. 


\section{Conclusions}

This systematic review of qualitative studies provides an in-depth understanding of the barriers to, and facilitators of, delivery and participation in prison OAT programmes in diverse contexts and from the perspectives of a range of stakeholders. The review highlights the importance of drawing on interpretivist approaches and suggests that the resulting contextualised and nuanced understandings of the benefits of OAT programmes are crucial to improving prison systems and prisoner participation.

A lack of a clear understanding of their role as part of harm reduction and OUD treatment programmes, as well as doubts relating to the substances they employ, are critical barriers to OAT programmes in both higher-income and lower/middle income countries. In addition, prison system organisation and (lack of) structures may disrupt programmes within prisons, prisoner transfer between prisons and post-release care. At the same time, it is difficult for stakeholders and healthcare staff effectively to mitigate poor implementation of the OAT programmes in prisons given a lack of resources, particularly in LMIC. The family-centred approach to healthcare services in prisons in some LMIC, and stigmatisation of OAT programmes in all settings have fostered feelings of vulnerability among prisoners and further deter participation.

Stakeholders both in high- and LMIC should focus on strengthening the facilitators and mitigating the barriers to improved implementation and to scaling-up the programmes. This review also indicates the need to develop open discussion between all stakeholders (prison managers, healthcare staff, prison officers and prisoners) to determine how best to coordinate programme implementation. It is clear that some of the identified barriers could be addressed through providing information about 
methadone (where used) and harm reduction that engages with local understandings and is cognisant of the ways such understandings are reinforced.

This paper further indicates there is an urgent need to develop more qualitative work, incorporating varied methods, on delivering prison OAT programmes. Such work should take diverse contexts including of limited resources, and the organisation of health care around family rather then the individual into account, to minimize the impact of harms related to OUDs in prisons. The importance of undertaking systematic reviews that take into full account the value of qualitative data in providing a more indepth and broader understanding of these issues, of the diverse meanings of methadone and of the materialities of its provision is also highlighted. Notably, the quotations included in this review provide powerful illustrations of stakeholders' circumstances. Furthermore, the different significance of money for prisoners and staff within higher and LMIC prisons, and of culturally-inflected organisation of health care is perhaps more easily understood through such quotations. Such nuances are more likely to be lost in the necessarily more general terms used in quantitative work or, indeed, where interpretation of qualitative data is undertaken by culturallyhomogenous research teams.

\section{References}

Altice, F. L., Azbel, L., Stone, J., Brooks-Pollock, E., Smyrnov, P., Dvoriak, S., Taxman, F. S., El-Bassel, N., Martin, N. K., Booth, R., Stöver, H., Dolan, K. and Vickerman, P. (2016) The perfect storm: incarceration and the high-risk environment perpetuating transmission of HIV, hepatitis $\mathrm{C}$ virus, and tuberculosis in Eastern Europe and Central Asia. Lancet (London, England), 388(10050), pp. 1228-1248.

Asher, H. (2013) Methadone prescribing in local prisons in England. Drugs \& Alcohol Today, 13 (4), pp. 234-243. 
Awgu, E., Magura, S. and Rosenblum, A. (2010) Heroin-dependent inmates' experiences with buprenorphine or methadone maintenance. Journal of Psychoactive Drugs, 42 (3), pp. 329-346.

Azbel, L., Wegman, M. P., Polonsky, M., Bachireddy, C., Meyer, J., Shumskaya, N., Kurmanalieva, A., Dvoryak, S. and Altice, F. L. (2018) Drug injection within prison in Kyrgyzstan: elevated HIV risk and implications for scaling up opioid agonist treatments. International journal of prisoner health, 14(3), pp. 175-187.

Booth, A. (2006) Australian supermodel?: a practical example of evidence-based library and information practice (EBLIP). Health Information \& Libraries Journal, 23 (1), pp. 69-72.

Carlin, T. (2005) An exploration of prisoners' and prison staff's perceptions of the methadone maintenance programme in Mountjoy Male Prison, Dublin, Republic of Ireland. Drugs: Education, Prevention \& Policy, 12 (5), pp. 405-416.

Chandler, R.K., Fletcher, B.W. and Volkow, N.D. (2009) Treating drug abuse and addiction in the criminal justice system: improving public health and safety. Journal of the American Medical Association, 301 (2), pp. 183-190.

Culbert, G.J., Waluyo, A., Iriyanti, M., Muchransyah, A.P., Kamarulzaman, A. and Altice, F.L. (2015) Within-prison drug injection among HIV-infected male prisoners in Indonesia: a highly constrained choice. Drug and Alcohol Dependence, 149, pp. 7179.

Fazel, S., Yoon, I. A. and Hayes, A. J. (2017) Substance use disorders in prisoners: an updated systematic review and meta-regression analysis in recently incarcerated men and women. Addiction (Abingdon, England), 112 (10), pp. 1725-1739.

Fazel, S., Bains, P, Doll, H. (2006) Substance abuse and dependence in prisoners: a systematic review. Addiction, 101(2), pp. 181-191.

Friedmann, PD., Hoskinson, R., Gordon, M,, Schwartz, R., Kinlock, T., Knight, K. (2012) Medication-assisted treatment in criminal justice agencies affiliated with the Criminal Justice-Drug Abuse Treatment Studies (CJ-DATS): availability, barriers, and intentions. Subst Abus. 33 (9).

Gordis, E. (1991) From science to social policy: an uncertain road. Journal of Studies on Alcohol, 52 (2), pp. 101-109.

Grant, M.J. (2004) How does your searching grow?: a survey of search preferences and the use of optimal search strategies in the identification of qualitative research. Health Information \& Libraries Journal, 21 (1), pp. 21-32.

Grella CE, Ostile E, Scott CK, Dennis M, Carnavale J. A Scoping Review of Barriers and Facilitators to Implementation of Medications for Treatment of Opioid Use Disorder within the Criminal Justice System. International Journal of Drug Policy. 2020 Jul 1;81:102768. 
Hedrich, D., Alves, P., Farrell, M., Stöver, H., Møller, L. and Mayet, S. (2012) The effectiveness of opioid maintenance treatment in prison settings: a systematic review. Addiction, 107 (3), pp. 501-517.

Heimer, R., Catania, H., Newman, R.G., Zambrano, J., Brunet, A. and Ortiz, A.M. (2006) Methadone maintenance in prison: evaluation of a pilot program in Puerto Rico. Drug \& Alcohol Dependence, 83 (2), pp. 122-129.

Jhanjee, S. (2014) Evidence based psychosocial interventions in substance use. Indian Journal of Psychological Medicine, 36 (2), pp. 112.

Johnstone, A., Duffy, T. and Martin, C. (2011) Subjective effects of prisoners using buprenorphine for detoxification. International Journal of Prisoner Health, 7 (4), pp. 5265.

Jürgens, R., Nowak, M., Day, M. (2011) HIV and incarceration: prisons and detention. $J$ Int AIDS So,14 (26).

Larney, S. (2010) Does opioid substitution treatment in prisons reduce injectingrelated HIV risk behaviours?: a systematic review. Addiction, 105 (2), pp. 216-223.

Larney, S., Zador, D., Sindicich, N., Dolan, K. (2017) A qualitative study of reasons for seeking and ceasing opioid substitution treatment in prisons in New South Wales, Australia. Drug and alcohol review, 36 (3), pp. 305-310.

Malta, M., Varatharajan, T., Russell, C., Pang, M., Bonato, S., Fischer, B. (2019) Opioid-related treatment, interventions, and outcomes among incarcerated persons: A systematic review. Plos Medicine.

McKenzie, M., Nunn, A., Zaller, N. D., Bazazi, A. R., \& Rich, J. D. (2009). Overcoming obstacles to implementing methadone maintenance therapy for prisoners: implications for policy and practice. Journal of opioid management, 5 (4), pp. 219-227.

Mitchell, S.G., Kelly, S.M., Brown, B.S., Reisinger, H.S., Peterson, J.A., Ruhf, A., Agar, M.H. and Schwartz, R.P. (2009) Incarceration and opioid withdrawal: the experiences of methadone patients and out-of-treatment heroin users. Journal of Psychoactive Drugs, 41 (2), pp. 145-152.

Mjåland, K. (2016) Exploring prison drug use in the context of prison-based drug rehabilitation. Journal Drugs: Education, Prevention and Policy, 23 (2), pp. 154-162.

Mjåland, K. (2015). The paradox of control: An ethnographic analysis of opiate maintenance treatment in a Norwegian prison. Int $J$ Drug Policy, 26 (8), pp. 781-9.

Moradi, G., Farnia, M., Shokoohi, M., Shahbazi, M., Moazen, B. and Rahmani, K. (2015) Methadone maintenance treatment program in prisons from the perspective of medical and non-medical prison staff: a qualitative study in Iran. International Journal of Health Policy and Management, 4 (9), pp. 583-589. 
Morineau, G., Bollen, L.J., Syafitri, R.I., Nurjannah, N., Mustikawati, D.E. and Magnani, R. (2012) HIV prevalence and risk behaviours among injecting drug users in six indonesian cities implications for future HIV prevention programs. Harm Reduct J, 9 (37).

Mundt, A. P., Baranyi, G., Gabrysch, C. and Fazel, S. (2018) Substance Use During Imprisonment in Low- and Middle-Income Countries. Epidemiologic reviews, 40 (1), pp. 70-81.

National Institute for Health and Care Excellence (2012) Methods for the development of NICE public health guidance. 3rd ed. London: NICE. Retrieved 10 ${ }^{\text {th }}$ March 2018 from https://www.nice.org.uk/process/pmg4/paper/introduction.

Page, P.G., Templeton, L., Grace, S., Roberts, P., McKeganey, N., Russel, C., Liebling, A., Kougiali, Z., Lloyd, C. (2016) Conspicuous by their abstinence: The limited engagement of heroin users in English and Welsh Drug Recovery Wings. International Journal of Drug Policy, 29, pp. 49-56.

Perkins, E.B. and Sprang, G. (2013) Results from the Pro-QOL-IV for substance abuse counsellors working with offenders. International Journal of Mental Health and Addiction, 11 (2), pp. 199-213.

Rhodes, T., Azbel, L., Lancaster, K. And Meyer, J. (2019). The becoming-methadonebody: on the onto-politics of health intervention translations. Sociology of Health \& IIIness, 41 (8), pp. 1618-163.

Rhodes, T. (2002). The 'risk environment': a framework for understanding and reducing drug-related harm. International Journal of Drug Policy, 13 (2), pp. 85-94.

Brinkley-Rubinstein , L.B., Peterson, M., Clarke, J., Macmadu, A., Truong, A., Pognon, K., Parker, M., Marshall, B.D.L., Green, T., Martin, R., Stein, L., Rich, J.D. (2019) The benefits and implementation challenges of the first state-wide comprehensive medication for addictions program in a unified jail and prison setting. Drug and Alcohol Dependence, 205 (1).

Sander, G., Scandurra, A., Kamenska, A., MacNamara, C., Kalpaki, C., Bessa, C.F., Laso, G.N., Parisi, G., Varley, L., Wolny, M. and Moudatsou, M. (2016) Overview of harm reduction in prisons in seven European countries. Harm Reduction Journal, 13 (1), pp. 28.

Stöver, H., Casselman, J. and Hennebel, L., (2006) Substitution treatment in European prisons: a study of policies and practices in 18 European countries. International Journal of Prisoner Health, 2 (1), pp. 3-12.

Strang, J., Sheridan, J., Hunt, C., Kerr, B., Gerada, C. and Pringle, M. (2005) The prescribing of methadone and other opioids to addicts: national survey of GPs in England and Wales. British Journal of General Practice, 55 (515), pp. 444-451. 
WHO. (1993) Guidelines on HIV infection and AIDS in prisons. Geneva: World Health Organization. $\quad$ Retrieved $05^{\text {th }} \quad$ March 2018 from http://whqlibdoc.who.int/hq/1993/WHO_GPA_DIR_93.3.pdf.

WHO/UNODC/UNAIDS. (2004) WHO/UNODC/UNAIDS position paper Substitution maintenance therapy in the management of opioid dependence and HIV/AIDS prevention. Geneva: World Health Organization. Retrieved 05 http://www.who.int/substance_abuse/publications/en/PositionPaper_English.pdf?ua= 1.

Zamani, S., Farnia, M., Tavakoli, S., Gholizadeh, M., Nazari, M., Seddighi, A., Setayesh, H., Afshar, P. and Kihara, M. (2010) A qualitative inquiry into methadone maintenance treatment for opioid-dependent prisoners in Tehran, Iran. The International Journal on Drug Policy, 21 (3), pp. 167-172. 